\title{
MIT
}

\section{Risk and Reward in the Orphan Drug Industry}

The MIT Faculty has made this article openly available. Please share how this access benefits you. Your story matters.

\begin{tabular}{|l|l|}
\hline As Published & $10.3905 /$ JPM.2019.45.5.030 \\
\hline Publisher & Pageant Media US \\
\hline \hline Version & Original manuscript \\
\hline Citable link & https://hdl.handle.net/1721.1/134802 \\
\hline Terms of Use & Creative Commons Attribution-Noncommercial-Share Alike \\
\hline Detailed Terms & http://creativecommons.org/licenses/by-nc-sa/4.0/ \\
\hline
\end{tabular}




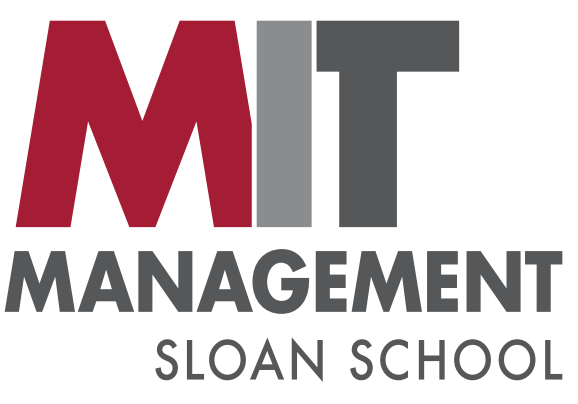

\section{MIT Sloan School of Management}

MIT Sloan School Working Paper 5582-18

\section{Risk and Reward in the Orphan Drug Industry}

Andrew W. Lo and Richard T. Thakor

This work is licensed under a Creative Commons AttributionNonCommercial License (US/v4.0)

(cc) BY-NC

http://creativecommons.org/licenses/by-nc/4.0/

September 24, 2018 


\title{
Risk and Reward in the Orphan Drug Industry ₹
}

Andrew W. Lo ${ }^{1-3, \dagger}$ and Richard T. Thakor ${ }^{4}$

${ }_{1}^{1}$ MIT Sloan School of Management and Laboratory for Financial Engineering

Cambridge, MA 02142, U.S.A.

${ }^{2}$ MIT Computer Science and Artificial Intelligence Laboratory \& Department of Electrical

Engineering and Computer Science

Cambridge, MA 02139, U.S.A.

${ }^{3}$ Santa Fe Institute

Santa Fe, NM 87501, U.S.A.

${ }^{4}$ University of Minnesota, Carlson School of Management

Minneapolis, MN 55455, U.S.A.

+Corresponding Author: alo-admin@mit.edu

This Version: September 23, 2018

\begin{abstract}
Thanks to a combination of scientific advances and economic incentives, the development of therapeutics to treat rare or "orphan" diseases has grown dramatically in recent years. With the advent of FDA-approved gene therapies and the promise of gene editing, many experts believe we are at an inflection point in dealing with these afflictions. In this paper we propose to document this inflection point by measuring the risk and reward of investing in the orphan drug industry. We construct a stock market index of 39 publicly traded companies that specialize in developing drugs for orphan diseases and compare the financial performance of this index, which we call ORF, to the broader biopharmaceutical industry as well as the overall stock market from 2000 to 2015. While ORF underperformed other biopharma companies and the overall stock market in the early 2000s, its performance has improved over time: from 2010 to 2015 , ORF returned $608 \%$, far exceeding the returns of $317 \%, 320 \%$, and $305 \%$ of the S\&P, NASDAQ, and NYSE/ARCA Biotech indexes, respectively, and the 83\% of the S\&P 500. ORF does have higher volatility than the other indexes, but still outperforms even on a risk-adjusted basis, with a Sharpe ratio of 1.24 versus Sharpe ratios of 1.17, 1.14, and 1.05, respectively for the other three biotech indexes, and 0.71 for the S\&P 500 . However, ORF has a market beta of 1.16 which suggests significant correlation to the aggregate stock market and less diversification benefits than traditional pharmaceutical investments.
\end{abstract}

\footnotetext{
₹ We thank Joyce Hong for research assistance. Research support from the MIT Laboratory for Financial Engineering is gratefully acknowledged. The views and opinions expressed in this article are those of the authors only, and do not necessarily represent the views and opinions of any institution or agency, any of their affiliates or employees, or any of the individuals acknowledged above.
} 


\section{Introduction}

The term "orphan disease" typically refers to rare conditions that affect relatively small patient populations, such as amyotrophic lateral sclerosis (ALS), chronic myelogenous leukemia, and Gaucher disease, many of which are fatal or extremely debilitating. Although any single orphan disease is by definition uncommon, it is estimated there are over 7,000 types of such diseases and the population of Americans with an orphan disease from 25 to 30 million, exceeding the total number of U.S. cancer patients.

Until the passage of the Orphan Drug Act (ODA) in 1983, the biopharmaceutical industry showed little interest in developing therapies for orphan indications. In the decade before the ODA, only 10 industry-sponsored orphan drugs were brought to market in the United States. However, thanks to various economic incentives created by the ODA (e.g., tax benefits, extended exclusivity, and priority FDA review), combined with technological breakthroughs like efficient whole-genome sequencing and rational drug design methods, over 600 orphan drug indications have been approved by the FDA between 1983 and 2017 based on more than 450 distinct drug products. ${ }^{1}$ In a number of cases, fatal conditions such as chronic myeloid leukemia and Gaucher disease have been transformed into chronic but manageable conditions with the appropriate medication. Moreover, the advent of gene therapy now holds out the promise of cures to certain orphan diseases, of which $80 \%$ are genetic in origin.

These factors have contributed to what many consider to be an inflection point in the treatment of orphan diseases, reflected in the financial performance of the biopharmaceutical companies producing orphan drugs. A case in point is Alexion Pharmaceuticals, a U.S. company founded in 1992 that received FDA approval in 2007 for Soliris, a treatment for paroxysmal hemoglobinuria, a rare blood disorder. Since its initial public offering in 1996, Alexion has yielded an average compound annual return of $29 \%$ (through August 10, 2018), and on May 24, 2012, the stock was added to the S\&P 500 index. Of course, not all orphan drug companies are as successful. Even those companies that succeed to the point of going public still bear considerable risk. The amount of risk and whether the returns to investors are commensurate with that risk are the subjects of this study.

We propose to measure the financial performance of the orphan drug industry by constructing an index of U.S. companies focused exclusively on developing therapies for orphan diseases. We identify 39 such companies, construct a value-weighted return index with these companies as constituents, and investigate the statistical properties of this index which we shall refer to as ORF. In the early 2000s, we find that orphan drug companies as an aggregate were not as attractive an investment as other drug companies, i.e., ORF had worse

${ }^{1}$ Lanthier (2017). See also Lichtenberg and Waldfogel (2003), who document increases in consumption and longevity for individuals with less common diseases, due to the passage of the Orphan Drug Act.

23 Sep 2018

(C) 2018 by Lo and Thakor

Page 1 of 24 All Rights Reserved 
returns with substantially higher risk. However, its performance has improved over time. During the last five years ORF has outperformed both the pharma and biotech sector indexes in terms of its risk-return profile. Overall, an investment in orphan drug companies from 2000 to 2015 would have fared better than investments in either pharma or biotech, even after adjusting for risk. ${ }^{2}$

It is useful to compare ORF to other indexes in the biopharmaceutical sector. ORF has consistently higher volatility than the pharma index, indicating substantial risk. While the volatility is slightly higher than the biotech index, it moves closely with that index. The volatility of these indexes has shown a secular decline since 2000 , and the volatility of the indexes also has less dispersion compared to the early 2000s. However, the higher volatility in the early 2000 s may be due to the bursting of the tech bubble.

Market betas for the ORF and biotech indexes in general decreased between 2000 and 2010, spiking between 2012 and 2013, and have since been declining. The betas of the ORF and biotech indexes are quite similar over time, but when calculated over longer horizons, ORF has the higher beta, beginning in 2005. The pharma index consistently posts lower betas than the ORF or biotech indexes. The conclusion is that orphan drugs carry significant systematic risk relative to the market.

In terms of downside risk, the maximum drawdowns of ORF are consistently greater in magnitude than the other indexes (i.e. they are more negative), showing that there is a potential for greater tail risk of negative returns for orphan drugs. The exception is the kmeans biotech index, which has comparable maximum drawdowns. However, the drawdowns have been smaller in magnitude (less negative) over time, indicating that there has been improvement.

\section{Index Construction and Empirical Methodology}

Our goal is to construct an index with companies that undertake pure-play orphan drug development. We therefore define an orphan drug company as:

(1) A company that has an expressed and exclusive commitment to the development of orphan drugs (as determined by their mission statement);

(2) A company that is devoted specifically to one or more orphan disease areas; or

(3) A company whose pipeline consists only of orphan drugs.

\footnotetext{
${ }^{2}$ Our results are also consistent with recent evidence that suggests that Orphan Drug Designations can serve as a positive signal for stock market investors at the time of an Initial Public Offering (IPO); see Gorry and Useche (2017).
} 
To identify the set of constituent companies for our index, we obtain the entire history of orphan drug designations to date from the FDA's Orphan Drug Designation and Approvals database. ${ }^{3}$ From this history, we identify all companies that have achieved orphan drug status for at least one product. From these companies, we manually identify the subset of companies that adhere to our definition of an orphan drug company. This yields a total of 170 companies, of which 39 are U.S. publicly traded companies. The complete list of companies that we consider, as well as the dates for which we have data, are included in the Appendix.

For these companies, we obtain daily stock return data from the CRSP database from January 3, 2000 to December 31, 2015. We choose 2000 as our starting year, since that is the first year in which there is a quarter with 10 or more orphan drug companies for which we can construct our index. This provides us with a total of 59,805 daily stock return observations, which translates to 4,025 daily return observations for our index.

Using the stock return data for these companies, we construct a value-weighted total return index that is rebalanced quarterly. ${ }^{4}$ More specifically, at the beginning of each quarter, we calculate the weight of each company in the index as its proportion of the total market capitalization of all active orphan drug companies as of that date. The weights of each company vary across time depending on the individual company returns until the next rebalancing date, when new companies may enter the index and the weights are re-adjusted. The overall return of the index is thus a weighted average of the daily returns of the constituent companies. Mathematically, the return of the index on a given date $t$ is given by:

$$
R_{t}^{\mathrm{ORF}}=\sum_{j=1}^{N}\left(\frac{\operatorname{Val}_{j, t-1}}{\sum_{i=1}^{N} V a l_{i, t-1}}\right) R_{j, t}
$$

where $R_{j, t}$ is the return of stock $j$ on date $t$, which is multiplied by the weight of stock $j$ (a function of its previous-day market capitalization $V_{a l} l_{j, t-1}$ ). Using these returns, we also calculate various risk characteristics and risk-adjusted returns of ORF over time, including the stock return volatility, Sharpe ratios, CAPM and Fama-French 3-factor alphas and betas, and maximum drawdowns.

We compare the return and risk characteristics of ORF to those of broad indexesthe S\&P 500 and Nasdaq indexes - as well as widely used pharma and biotech indexes, including the NYSE ARCA Pharma, the NYSE ARCA Biotech, the Nasdaq Biotech, and the S\&P

3 FDA Orphan Drug Designations and Approvals Database.

https://www.accessdata.fda.gov/scripts/opdlisting/oopd/

${ }^{4}$ The returns of our index are similar if we instead construct an equal-weighted index that is rebalanced quarterly. 
500 Biotech. ${ }^{5}$ However, as noted by Thakor et al. (2017), a significant concern with comparing biotech indexes is that their return characteristics are very sensitive to the inclusion of specific companies, due to the outsized performance of a handful of companies. As a result, for comparison we also include "k-means" pharma and biotech index returns taken from Thakor et al. (2017), which classify companies into the pharma or biotech sectors dynamically over time using observable characteristics via machine learning techniques. ${ }^{6}$

\section{Results: Returns}

We begin by examining the returns of the ORF index compared to that of the other indexes. In the top graph of Figure 1, we plot the cumulative returns of ORF compared to the broad S\&P 500 and Nasdaq indexes from the beginning of 2000 to the end of 2015. In terms of cumulative returns, ORF appears to slightly outperform the S\&P 500 from 2000 to 2004, but then begins to underperform the S\&P 500 (and slightly outperform the Nasdaq) until around 2008. After that, the performance of ORF improves substantially, and is greater than that of both the S\&P 500 and the Nasdaq by a wide margin. For comparison purposes, a $\$ 1$ investment in ORF in the beginning of 2000 would have yielded just above $\$ 6$ at the end of 2015 , whereas the same $\$ 1$ investment in either the S\&P 500 or the Nasdaq would have yielded around $\$ 1.50$ by the end of 2015 .

\section{[Insert Figure 1 Here]}

The middle graph of Figure 1 compares the cumulative returns of ORF to those of the NYSE ARCA Pharma index as well as the $k$-means Pharma index from Thakor et al. (2017). The performance of the ARCA Pharma and k-means Pharma indexes are quite similar until about 2010, when the $k$-means Pharma index overtakes the ARCA Pharma index. While ORF appears to underperform these pharma indexes until roughly 2008, after 2010 ORF begins to substantially outpace the pharma indexes.

\footnotetext{
${ }^{5} \mathrm{~A}$ possible concern with constructing these returns is that they are subject to autocorrelation. In untabulated results, we calculate the autocorrelation coefficients for each index over each year, 5-year sub-periods, and the entire sample period. We also perform Breusch-Godfrey LM tests, and confirm that, while there are a few individual years with some significant autocorrelation, there is no evidence of autocorrelation over the entire sample period or 5-year sub-periods for the orphan drug index. Similarly, for every other index except for the S\&P 500 and $k$-means Biotech indexes, there is no significant autocorrelation over the entire sample. The biotech indexes, however, do have some significant autocorrelation from 2005 to 2009. Taken in total, the tests suggest that autocorrelation is unlikely to have a strong effect on our results.

${ }^{6}$ More specifically, the Thakor et al. (2017) indexes are constructed so that there are a sample of "seed" companies in each year that are classified as either pharma or biotech. The $k$-means machine learning algorithm then looks at all other companies in the sample in that year, and calculates distances between those companies and the seed companies based on observable characteristics such as the number of employees, R\&D expenses, total asset value, intangible assets, cash holdings, sales, company age, and so on. The classifications are recalculated for each year, and thus the classification is dynamic-a company may be biotech in one year, but eventually may become pharma.
} 
The bottom graph of Figure 1 compares ORF to four biotech indexes-the NYSE ARCA Biotech, S\&P 500 Biotech, Nasdaq Biotech, and $k$-means Biotech indexes. As can be seen from the figure, the cumulative returns from the NYSE ARCA Biotech index dominate those of the other biotech indexes as well as that of ORF over the entire period. In particular, a $\$ 1$ investment in the ARCA Biotech index at the beginning of 2000 would have yielded about $\$ 10$ at the end of 2015. The cumulative returns on ORF, however, stay in line with the remaining indexes until about 2011, after which it overtakes the remaining indexes. While the S\&P 500 and Nasdaq Biotech indexes perform slightly more poorly than ORF, the $k$ means Biotech index seems to post substantially lower cumulative returns.

This dramatic diversity in returns between the biotech indexes are in line with the results of Thakor et al. (2017), who point out that the composition of companies in a biotech index has a very strong effect on the overall picture of performance. For example, the ARCA Biotech index was originally composed of 30 constituents (a number increased in 2014), each of which was required to have a market capitalization of greater than $\$ 1$ billion and minimum average trading values. As a result, the index selects for companies with exceptionally strong performance, such as Amgen and Gilead. This is able to exert a disproportionately large effect on the pattern of realized returns, thus making the index unrepresentative of investment in the industry as a whole. Consistent with this, the cumulative performance of the other biotech indexes is much lower than that of the ARCA Biotech index, suggesting that the performance of ORF does indeed surpass that of biotech, at least over the past five years.

In order to more closely examine the evolution of these returns over time, Panel A of Table 1 provides the yearly compounded returns for each of the indexes. While the NYSE ARCA Biotech index posts higher cumulative returns over the sample period of $874 \%$, there are a number of years where ORF outperforms all of the other indexes. This performance has become more consistent, starting in 2010, ranging from a low of $12 \%$ in 2015 to a high of $53.5 \%$ in 2013. Examining the compounded returns at 5-year intervals, Panel B of Table 1 shows the broad pattern in the evolution of returns for ORF. From 2000 to 2004, the index posted returns of $-34 \%$, underperforming every index except for the Nasdaq. From 2005 to 2009 , it then posted returns of 31\%, outperforming every index except for the NYSE ARCA Biotech, which achieved returns of 73\%. Finally, in the most recent period from 2010 to 2015 , ORF posted returns of $608 \%$, substantially higher than every other index, including the biotech indexes which had returns just over $300 \%$.

[Insert Table 1 Here]

Thus, the returns of ORF have shown a strong pattern of improvement over time, within the past few years overtaking all other indexes, including the ARCA Biotech index, despite the composition issue mentioned above. 


\section{Results: Risk Characteristics}

While the previous results are suggestive of the performance of the index, they do not take into account the amount of risk taken on by an investor in order to realize those returns. In other words, an investor that has gained high returns may have simply been compensated for taking on a high amount of risk. We therefore now turn to comparing the amount of risk carried by each index. We begin by looking at the overall risk as measured by the volatility of stock returns, and then we turn to systematic risk as measured by beta, the tendency of movements in the index to reflect those in the market. Finally, we try to examine the downside tail risk by examining the maximum drawdowns of each index.

\section{Volatility}

The volatility of each index is shown over time in Figure 2. These volatilities are calculated by taking the standard deviation of each index's returns over the indicated period. There are several noteworthy patterns. First, the volatility of each of the indexes has declined over time. Second, the differences in volatility between the indexes have also declined over time since the early 2000s. Third, the volatilities of the biotech indexes are very similar over time, and higher than those of the pharma and broad indexes. Finally, ORF consistently has a substantially higher volatility than the broad indexes and pharma indexes, but only slightly higher than that of the biotech indexes, with which it remains closely in line. The volatility numbers in each year and for 5-year periods are provided in Table 2. Consistent with the pattern in Figure 2, ORF has a volatility of 0.38 over the entire sample period, substantially higher than that of the pharma and S\&P 500 indexes (which are between 0.19 and 0.20 ), but only slightly higher than the biotech indexes (which range from 0.31 to 0.35 ). The table also reinforces the pattern of decline, with ORF posting a volatility of 0.50 in the interval from 2000 to 2005, a volatility of 0.33 in the interval from 2005 to 2009 , and a volatility of 0.30 in the most recent interval from 2010 to 2015 . Taken together, these results imply that, while ORF appears to have substantial risk, it is generally in line with the risk found in the biotech sector.

[Insert Figure 2 Here]

[Insert Table 2 Here]

\section{Betas}

We next examine the systematic risk of the indexes, in order to get a sense of how much of the risk in the previous section is driven by co-movements with broader factors such as the market or economy. We do so by calculating the market betas of each index over time, controlling for the Fama and French (1993) size and value factors. These estimates over time are shown in Figure 3. Between 2000 and 2011, the betas for the orphan drug and biotech indexes decline over time from roughly 1.5 to just below 1.0, which is consistent with the evidence in Thakor and Lo (2015) that suggests increased competition in the biopharma 
sector. The betas for these indexes then spike in 2012 and 2013, but have fallen since. Overall, the betas of the orphan drug and biotech indexes appear to be very similar to each other. In contrast, the betas of the NYSE ARCA Pharma and $k$-means Pharma indexes are consistently lower than the orphan drug and biotech indexes, ranging from a low of about 0.6 to a high of about 1.0. Since the mid-2000s, they have been relatively stable.

Table 3 provides both yearly and 5 -year beta estimates. Over the entire sample period from 2000 to 2015, the beta of ORF is 1.05, which is roughly the same size as the betas of the biotech indexes. However, when calculated over 5-year horizons, the betas of ORF are higher than all of the other indexes from 2005 onwards, with a beta of 0.97 in 2005-2009 and a beta of 1.16 from 2010-2015. This suggests that investments in orphan drugs carry substantial systematic risk, comparable or higher than that of the biotech sector. While this higher systematic risk may appear puzzling at first, it is in line with evidence in previous studies that drug development has a substantial financing risk, which in turn creates systematic risk. $^{7}$ Put differently, since the pure scientific risk involved in drug development is idiosyncratic (see Jørring et. al. (2017) for recent evidence), drug development co-varies with the state of the economy due to the need for large amounts of funding for the development process. Our results show that this issue may be even more of a concern for orphan drug development.

[Insert Figure 3 Here]

[Insert Table 3 Here]

\section{Maximum Drawdowns}

We examine one other measure of risk in order to ascertain the downside risk of investments in the indexes, the maximum drawdown of returns. For an index, the maximum drawdown calculates the largest drop in the value of the index for each period. In other words, it calculates the return performance from peak to trough within a period, in order to examine the largest possible drop in value. The maximum drawdowns for each year, for the entire sample period, and for 5-year intervals over the sample period are given in Table 4 .

\section{[Insert Table 4 Here]}

The maximum drawdown for $\mathrm{ORF}$ is $-82.5 \%$ over the entire sample period, which is consistently larger in magnitude (i.e. more negative) than those for the pharma indexes, which is between $-48 \%$ and $-52 \%$. Over the entire sample period, and for most years and sub-periods, the maximum drawdown for ORF is also larger in magnitude than for most of the biotech indexes. However, the $k$-means Biotech index has a maximum drawdown that exceeds those of ORF in a number of years and sub-periods. Furthermore, during the most recent period from 2010 to 2015 , the maximum drawdown for orphan drugs is $-32.7 \%$,

${ }^{7}$ See Golec and Vernon (2009), Myers and Howe (1997), Myers and Shyam-Sunder (1995), and Thakor et al. (2017), among others. 
slightly smaller (i.e. less negative) than those of the NYSE ARCA Biotech and $k$-means Biotech indexes, which are $-33.3 \%$ and $-33.7 \%$, respectively.

These maximum drawdowns indicate that there is a substantial amount of tail risk for ORF, higher than that for the pharma indexes. Depending on the specific biotech index, the drawdowns for orphan drugs are either smaller in magnitude or comparable to those for biotech. However, it is also worth noting that these drawdowns have been reducing in magnitude over time (becoming less negative), which may indicate that the downside risk of ORF has been diminishing over time.

\section{Results: Risk-Adjusted Returns}

Having compared the risk characteristics of ORF to the other biopharma indexes, we now reexamine the performance of the index after taking into the account the risk to investors. We examine two measures of risk-adjusted returns: Sharpe ratios and alphas.

\section{Sharpe Ratios}

We begin by calculating Sharpe ratios, in order to examine the returns per unit of risk for each index. The Sharpe ratio for any given time period is defined as:

$$
\text { Sharpe Ratio }=\frac{\mathrm{E}[R]-r_{f}}{\sigma}
$$

where $\mathrm{E}[R]$ is the mean daily index return over the given time period, $r_{f}$ is the risk-free rate of return, and $\sigma$ is the standard deviation of the index's returns over the time period. We annualize the Sharpe ratio by multiplying by $\sqrt{252}$, since there are 252 trading days in a given year.

The Sharpe ratios for each of the indexes are provided in Table 5 for each year, and for 5-year intervals. Over the entire sample from 2000 to 2015, the NYSE ARCA Biotech index has the highest Sharpe ratio of 0.535 , while ORF has the second-highest Sharpe ratio of 0.444 . These Sharpe ratios are slightly higher than for the other two biotech indexes (the S\&P 500 Biotech and Nasdaq Biotech), but are substantially higher than the Sharpe ratio of the $k$ means Biotech index. This reinforces the evidence for the composition effect on the index discussed earlier.

The Sharpe ratios of ORF are substantially higher than those of the broad S\&P 500 and Nasdaq indexes ( 0.118 and 0.117 , respectively) as well as the ARCA Pharma and $k$-means Pharma indexes ( 0.145 and 0.138 , respectively). The pattern of Sharpe ratios over time also indicates that in its early years from 2000 to 2004, ORF (with a Sharpe ratio of 0.031) outperformed (on a risk-adjusted basis) the S\&P 500 and Nasdaq broad indexes, all tested pharma indexes, and the $k$-means Biotech index, which all posted negative Sharpe ratios, but underperformed all of the other biotech indexes. From 2005 to 2009, ORF outperformed 
every index except for the NYSE ARCA Biotech. Finally, in the most recent period from 2010 to 2015, ORF posted a higher Sharpe ratio than all of the other indexes.

\section{[Insert Table 5 Here]}

Thus, even on a risk-adjusted basis, ORF has posted a consistently higher performance than the broad market or pharma indexes over the last 15 years. Its performance over time has also surpassed that of biotech indexes, especially over the most recent period, when it has surpassed even biotech indexes that focus on the most successful biotech companies.

\section{Alphas}

As another measure of performance after accounting for risk, we calculate alphas for each of the indexes in order to determine if they posted excess returns above those predicted by exposure to risk factors. We specifically calculate the alphas using the Fama and French (1993) three-factor model, running the following regression for each index $i$ in each time period:

$$
R_{i}-r_{f}=\alpha+\beta_{m k t}\left(R_{m k t}-r_{f}\right)+\beta_{\text {size }} S M B+\beta_{\text {value }} H M L+\varepsilon_{i}
$$

In the above equation, $R_{i}$ is the return of index $i, R_{m k t}$ is the market return, $S M B$ is the return of the size factor, and $H M L$ is the return of the value factor. ${ }^{8}$ The returns above those predicted by the factors is given by $\alpha$, and we annualize daily our alpha estimates.

Table 6 provides the estimates for alpha, as well as indicating their statistical significance. As can be seen, while the estimates for individual years are mostly insignificant, when calculated over the entire sample, the alphas are significant for ORF and the biotech indexes except for $k$-means, but not for the pharma indexes, which have an insignificant alpha. In line with the Sharpe ratios, the NYSE ARCA Biotech index has the highest alpha of 0.165 , consistent with the selection of high-performing biotech companies in the construction of the index. ORF has the second-highest alpha of 0.134 , and this alpha is also significant. While the alphas of all indexes are insignificant over the 2000-2004 and 20052009 intervals, ORF posts a large and significant alpha of 0.192 during the recent period, 2010-2015. This alpha is larger in magnitude than that of any other index, including those for biotech. Thus, it appears that ORF substantially outperforms the Biotech indexes in terms of excess returns.

ORF performs better than every tested index except for the NYSE ARCA Biotech index from 2000 to 2015, even on a risk-adjusted basis. However, the performance of ORF has

${ }^{8}$ Data for the factor returns are taken from Ken French's website:

http://mba.tuck.dartmouth.edu/pages/faculty/ken.french/data_library.html

23 Sep 2018

(C) 2018 by Lo and Thakor

Page 9 of 24

All Rights Reserved 
consistently improved over time, and even overtakes that of the NYSE ARCA Biotech index during the most recent period.

\section{Conclusion}

The financial performance of an orphan drug index consisting of 39 publicly traded companies focused solely on developing therapeutics for rare diseases is consistent with the view that we are at an inflection point in dealing with these afflictions. Although this index does reflect greater risk than aggregate stock market indexes like the S\&P 500 and the NYSE ARCA/Pharma index, the average return more than compensates investors for this higher risk. Moreover, the risk is commensurate with those of biotech indexes, but the orphan drug index has outperformed significantly over the recent past.

These results may be of particular relevance to the broader set of investors interested in gaining exposure to recent developments in rare disease therapeutics but who do not have either the resources or experience to engage in stock selection. 


\section{References}

Fama, Eugene F., and Kenneth R. French. Common risk factors in the returns on stocks and bonds. Journal of Financial Economics 33(1993): 3-56.

Golec, Joseph, and John A. Vernon. Financial risk of the biotech industry versus the pharmaceutical industry. Applied Health Economics and Health Policy 7(2009): 155-165.

Gorry, Philippe, and Diego Useche. Orphan Drug Designations as Valuable Intangible Assets for IPO Investors in Pharma-Biotech Companies. No. w24021. National Bureau of Economic Research, 2017.

Jørring, Adam, Andrew W. Lo, Tomas J. Philipson, Manita Singh, and Richard T. Thakor. Sharing R\&D risk in healthcare via FDA hedges. No. w23344. National Bureau of Economic Research, 2017.

Lanthier, Michael. 2017. Insights into rare disease drug approvals: trends and recent developments. NORD Rare Diseases \& Orphan Products Breakthrough Summit.

Lichtenberg, Frank R., and Joel Waldfogel. Does misery love company? Evidence from pharmaceutical markets before and after the Orphan Drug Act. No. w9750. National Bureau of Economic Research, 2003.

Myers, Stewart C., and Christopher Dwight Howe. A life-cycle financial model of pharmaceutical R\&D. Program on the pharmaceutical industry, Sloan School of Management, Massachusetts Institute of Technology, 1997.

Myers, Stewart C., and Lakshmi Shyam-Sunder. Measuring pharmaceutical industry risk and the cost of capital", in Competitive Strategies in the Pharmaceutical Industry, Helms, R.B., (ed). American Enterprise Institute for Public Policy: Washington DC, 1995.

Thakor, Richard T., Anaya, Nicholas, Zhang, Yuwei, Vilanilam, Christian, Siah, Kien Wei, Wong, Chi Heem, and Lo, Andrew W. Just how good an investment is the biopharmaceutical sector? Nature Biotechnology 35(2017), 1149-1157.

Thakor, Richard T., and Andrew W. Lo. Competition and R\&D financing decisions: Theory and evidence from the biopharmaceutical industry. No. w20903. National Bureau of Economic Research, 2015. 
Figure 1: Cumulative Returns from 2000 to 2015

This figure provides the value over time of a $\$ 1$ investment made on January 3, 2000. The top graph compares ORF to the broad S\&P 500 and Nasdaq indexes, the middle graph compares ORF to pharma indexes, while the bottom graph compares ORF to biotech indexes.

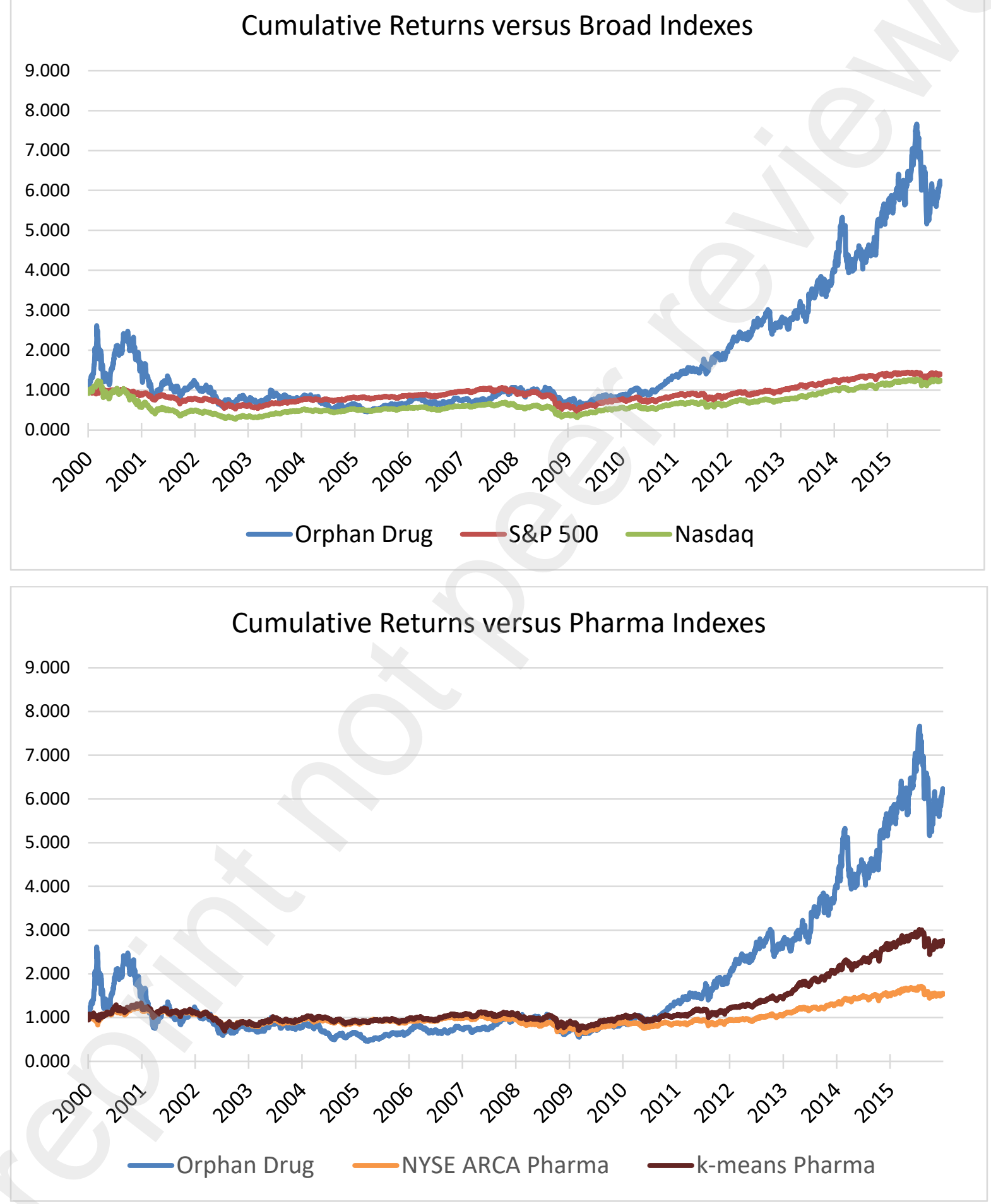




\section{Cumulative Returns versus Biotech Indexes}

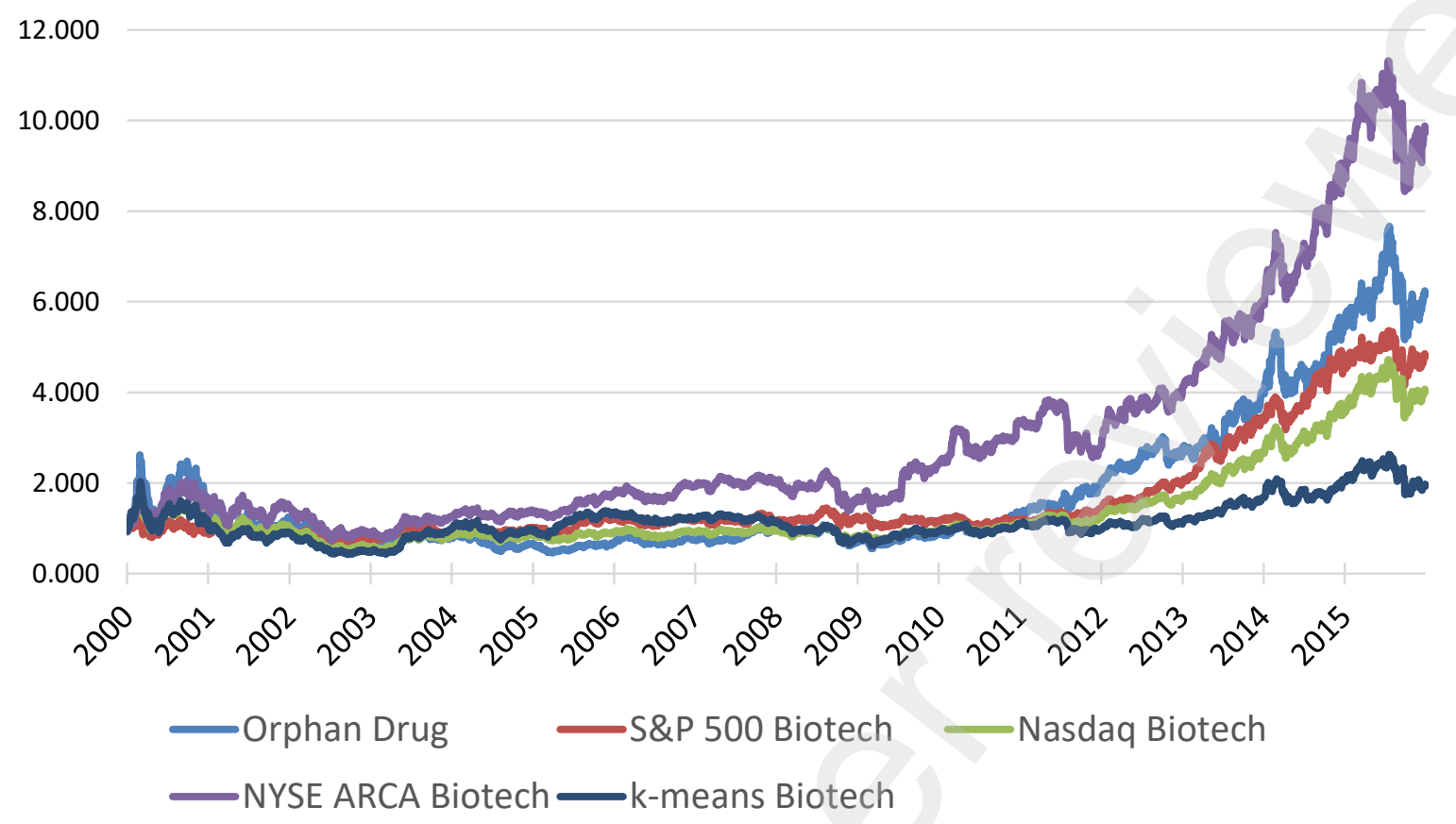


Figure 2: Yearly Volatility from 2000 to 2015

This figure provides the yearly stock return volatility for each index over time. Volatility estimates are calculated by taking the standard deviation of daily returns in each year. Estimates are annualized. The top graph compares ORF to the broad S\&P 500 and Nasdaq indexes, the middle graph compares ORF to pharma indexes, while the bottom graph compares ORF to biotech indexes.

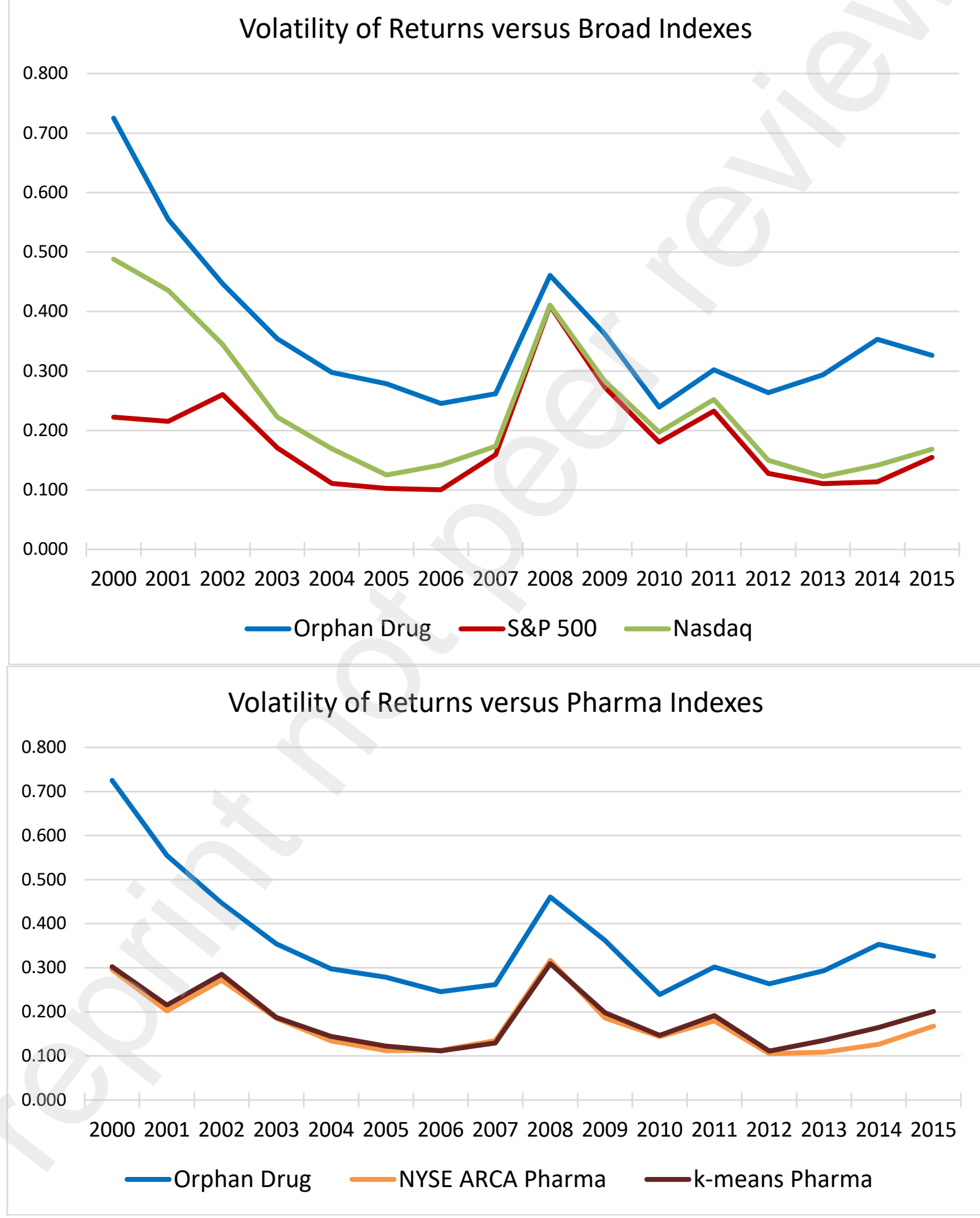




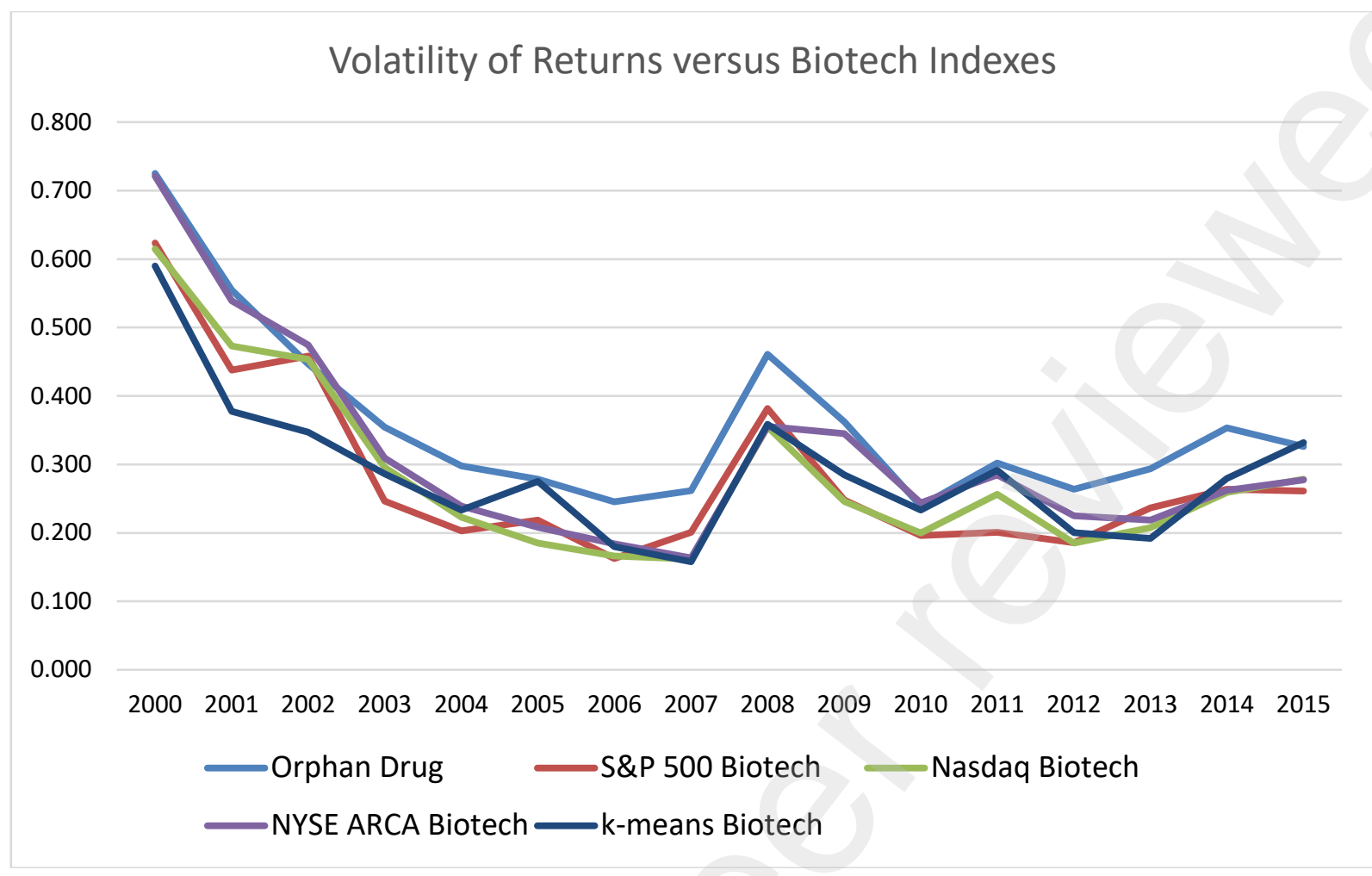




\section{Figure 3: Yearly Betas from 2000 to 2015}

This figure provides the yearly market beta estimates for each index over time. Beta estimates are calculated each year, and control for the Fama and French (1993) size and value factors. The top graph compares ORF to pharma indexes, while the bottom graph compares ORF to biotech indexes.
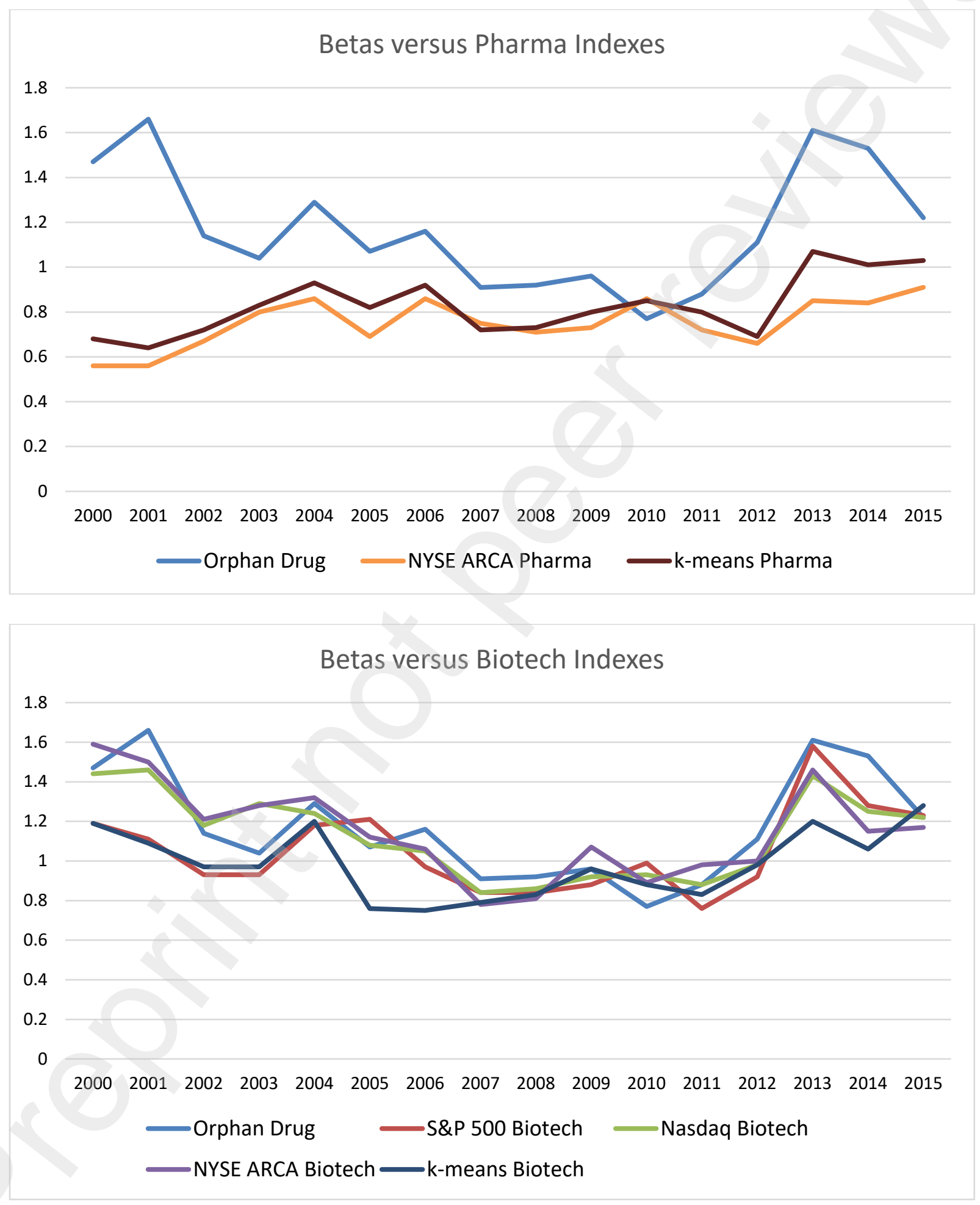


\section{Table 1: Yearly and 5-year Cumulative Returns from 2000 to 2015}

This table provides cumulative daily returns for the indicated time periods for each of the indexes. Panel A provides returns for each year, while Panel B provides returns for 5-year intervals.

Panel A: Yearly

\begin{tabular}{|c|c|c|c|c|c|c|c|c|c|}
\hline Year & $\begin{array}{l}\text { Orphan } \\
\text { Drug }\end{array}$ & $\begin{array}{l}S \& P \\
500\end{array}$ & Nasdaq & $\begin{array}{c}\text { S\&P } 500 \\
\text { Biotech }\end{array}$ & $\begin{array}{l}\text { Nasdaq } \\
\text { Biotech }\end{array}$ & $\begin{array}{c}\text { NYSE } \\
\text { ARCA } \\
\text { Biotech }\end{array}$ & $\begin{array}{c}\text { NYSE ARCA } \\
\text { Pharma }\end{array}$ & $\begin{array}{l}\text { k-means } \\
\text { Pharma }\end{array}$ & $\begin{array}{l}k \text {-means } \\
\text { Biotech }\end{array}$ \\
\hline 2000 & $69.0 \%$ & $-10.1 \%$ & $-39.3 \%$ & $-4.8 \%$ & $23.0 \%$ & $62.0 \%$ & $27.6 \%$ & $33.1 \%$ & $18.7 \%$ \\
\hline 2001 & $-27.2 \%$ & $-13.0 \%$ & $-21.1 \%$ & $-3.7 \%$ & $-16.2 \%$ & $-8.5 \%$ & $-14.8 \%$ & $-15.9 \%$ & $-23.5 \%$ \\
\hline 2002 & $-40.1 \%$ & $-23.4 \%$ & $-31.5 \%$ & $-20.4 \%$ & $-45.3 \%$ & $-41.7 \%$ & $-21.7 \%$ & $-23.3 \%$ & $-47.1 \%$ \\
\hline 2003 & $6.2 \%$ & $26.4 \%$ & $50.0 \%$ & $28.9 \%$ & $45.7 \%$ & $44.9 \%$ & $12.4 \%$ & $13.7 \%$ & $103.8 \%$ \\
\hline 2004 & $-15.1 \%$ & $9.0 \%$ & $8.6 \%$ & $7.6 \%$ & $6.1 \%$ & $11.0 \%$ & $-5.7 \%$ & $-3.8 \%$ & $-0.1 \%$ \\
\hline 2005 & $-1.4 \%$ & $3.0 \%$ & $1.4 \%$ & $18.3 \%$ & $2.8 \%$ & $25.1 \%$ & $1.1 \%$ & $2.0 \%$ & $35.2 \%$ \\
\hline 2006 & $13.4 \%$ & $13.6 \%$ & $9.5 \%$ & $-2.7 \%$ & $1.0 \%$ & $10.8 \%$ & $7.8 \%$ & $9.6 \%$ & $-8.4 \%$ \\
\hline 2007 & $39.7 \%$ & $3.5 \%$ & $9.8 \%$ & $-3.4 \%$ & $4.6 \%$ & $4.3 \%$ & $-2.6 \%$ & $0.5 \%$ & $-5.8 \%$ \\
\hline 2008 & $-30.9 \%$ & $-38.5 \%$ & $-40.5 \%$ & $10.3 \%$ & $-12.6 \%$ & $-17.7 \%$ & $-19.4 \%$ & $-14.3 \%$ & $-29.9 \%$ \\
\hline 2009 & $21.2 \%$ & $23.5 \%$ & $43.9 \%$ & $-7.3 \%$ & $15.6 \%$ & $45.6 \%$ & $13.3 \%$ & $11.8 \%$ & $16.5 \%$ \\
\hline 2010 & $53.0 \%$ & $12.8 \%$ & $16.9 \%$ & $1.9 \%$ & $15.0 \%$ & $37.7 \%$ & $-1.1 \%$ & $3.5 \%$ & $16.2 \%$ \\
\hline 2011 & $48.5 \%$ & $0.0 \%$ & $-1.8 \%$ & $22.4 \%$ & $11.8 \%$ & $-15.9 \%$ & $8.8 \%$ & $16.1 \%$ & $-9.0 \%$ \\
\hline 2012 & $32.7 \%$ & $13.4 \%$ & $15.9 \%$ & $37.7 \%$ & $31.9 \%$ & $41.7 \%$ & $11.0 \%$ & $18.7 \%$ & $12.9 \%$ \\
\hline 2013 & $53.5 \%$ & $29.6 \%$ & $38.3 \%$ & $74.3 \%$ & $65.6 \%$ & $50.6 \%$ & $26.7 \%$ & $44.9 \%$ & $51.6 \%$ \\
\hline 2014 & $36.3 \%$ & $11.4 \%$ & $13.4 \%$ & $32.6 \%$ & $34.1 \%$ & $47.6 \%$ & $13.8 \%$ & $24.2 \%$ & $20.8 \%$ \\
\hline 2015 & $12.2 \%$ & $-0.7 \%$ & $5.7 \%$ & $5.0 \%$ & $11.4 \%$ & $10.9 \%$ & $1.6 \%$ & $5.3 \%$ & $-5.0 \%$ \\
\hline $\begin{array}{l}\text { Entire } \\
\text { Sample }\end{array}$ & $516.0 \%$ & $39.1 \%$ & $23.1 \%$ & $379.3 \%$ & $301.5 \%$ & $874.3 \%$ & $53.3 \%$ & $172.7 \%$ & $93.6 \%$ \\
\hline
\end{tabular}

Panel B: 5-Year Intervals

\begin{tabular}{|c|c|c|c|c|c|c|c|c|c|}
\hline Interval & $\begin{array}{c}\text { Orphan } \\
\text { Drug }\end{array}$ & $\begin{array}{l}S \& P \\
500\end{array}$ & Nasdaq & $\begin{array}{c}\text { S\&P } 500 \\
\text { Biotech }\end{array}$ & $\begin{array}{l}\text { Nasdaq } \\
\text { Biotech }\end{array}$ & $\begin{array}{c}\text { NYSE } \\
\text { ARCA } \\
\text { Biotech } \\
\end{array}$ & $\begin{array}{c}\text { NYSE } \\
\text { ARCA } \\
\text { Pharma }\end{array}$ & $\begin{array}{l}k \text {-means } \\
\text { Pharma }\end{array}$ & $\begin{array}{c}k- \\
\text { means } \\
\text { Biotech }\end{array}$ \\
\hline $\begin{array}{l}2000- \\
2004\end{array}$ & $-34 \%$ & $-18 \%$ & $-47 \%$ & $1 \%$ & $-13 \%$ & $39 \%$ & $-10 \%$ & $-6 \%$ & $-2 \%$ \\
\hline $\begin{array}{l}2005- \\
2009\end{array}$ & $31 \%$ & $-8 \%$ & $4 \%$ & $14 \%$ & $10 \%$ & $73 \%$ & $-3 \%$ & $8 \%$ & $-5 \%$ \\
\hline $\begin{array}{l}2010- \\
2015\end{array}$ & $608 \%$ & $83 \%$ & $121 \%$ & $317 \%$ & $320 \%$ & $305 \%$ & $75 \%$ & $170 \%$ & $108 \%$ \\
\hline
\end{tabular}


Table 2: Volatility Estimates from 2000 to 2015

This table provides volatility estimates for the indicated time periods for each of the indexes. Volatility is calculated using the standard deviation of daily returns over the indicated time periods, and the estimates are annualized. Panel A provides volatilities for each year, while Panel B provides volatilities for 5-year intervals.

Panel A: Yearly

\begin{tabular}{|c|c|c|c|c|c|c|c|c|c|}
\hline Year & $\begin{array}{c}\text { Orphan } \\
\text { Drug }\end{array}$ & $\begin{array}{l}S \& P \\
500\end{array}$ & Nasdaq & $\begin{array}{c}\text { S\&P } 500 \\
\text { Biotech }\end{array}$ & $\begin{array}{l}\text { Nasdaq } \\
\text { Biotech }\end{array}$ & $\begin{array}{l}\text { NYSE ARCA } \\
\text { Biotech }\end{array}$ & $\begin{array}{c}\text { NYSE } \\
\text { ARCA } \\
\text { Pharma }\end{array}$ & $\begin{array}{c}k- \\
\text { means } \\
\text { Pharma }\end{array}$ & $\begin{array}{c}k- \\
\text { means } \\
\text { Biotech }\end{array}$ \\
\hline 2000 & 0.725 & 0.222 & 0.488 & 0.623 & 0.615 & 0.721 & 0.296 & 0.302 & 0.590 \\
\hline 2001 & 0.555 & 0.216 & 0.436 & 0.438 & 0.473 & 0.539 & 0.202 & 0.215 & 0.378 \\
\hline 2002 & 0.447 & 0.260 & 0.345 & 0.458 & 0.454 & 0.475 & 0.272 & 0.285 & 0.347 \\
\hline 2003 & 0.354 & 0.171 & 0.223 & 0.247 & 0.296 & 0.310 & 0.185 & 0.187 & 0.286 \\
\hline 2004 & 0.298 & 0.111 & 0.170 & 0.203 & 0.223 & 0.239 & 0.134 & 0.145 & 0.234 \\
\hline 2005 & 0.278 & 0.103 & 0.125 & 0.218 & 0.185 & 0.208 & 0.112 & 0.122 & 0.275 \\
\hline 2006 & 0.246 & 0.100 & 0.142 & 0.163 & 0.166 & 0.184 & 0.113 & 0.112 & 0.180 \\
\hline 2007 & 0.262 & 0.159 & 0.173 & 0.201 & 0.162 & 0.163 & 0.135 & 0.129 & 0.158 \\
\hline 2008 & 0.461 & 0.410 & 0.411 & 0.382 & 0.355 & 0.355 & 0.317 & 0.309 & 0.358 \\
\hline 2009 & 0.362 & 0.273 & 0.283 & 0.248 & 0.246 & 0.345 & 0.186 & 0.198 & 0.285 \\
\hline 2010 & 0.239 & 0.181 & 0.197 & 0.196 & 0.200 & 0.244 & 0.144 & 0.146 & 0.233 \\
\hline 2011 & 0.302 & 0.233 & 0.252 & 0.201 & 0.257 & 0.285 & 0.180 & 0.192 & 0.292 \\
\hline 2012 & 0.264 & 0.128 & 0.150 & 0.185 & 0.185 & 0.225 & 0.105 & 0.111 & 0.200 \\
\hline 2013 & 0.293 & 0.111 & 0.123 & 0.237 & 0.208 & 0.219 & 0.109 & 0.135 & 0.192 \\
\hline 2014 & 0.353 & 0.114 & 0.141 & 0.264 & 0.259 & 0.262 & 0.127 & 0.165 & 0.279 \\
\hline 2015 & 0.326 & 0.155 & 0.169 & 0.261 & 0.278 & 0.277 & 0.168 & 0.201 & 0.332 \\
\hline $\begin{array}{c}\text { Entire } \\
\text { Sample }\end{array}$ & 0.381 & 0.201 & 0.265 & 0.308 & 0.311 & 0.346 & 0.186 & 0.195 & 0.306 \\
\hline
\end{tabular}

Panel B: 5-Year Intervals

\begin{tabular}{|c|c|c|c|c|c|c|c|c|c|}
\hline Interval & $\begin{array}{c}\text { Orphan } \\
\text { Drug }\end{array}$ & $\begin{array}{l}\text { S\&P } \\
500\end{array}$ & Nasdaq & $\begin{array}{l}\text { S\&P } 500 \\
\text { Biotech }\end{array}$ & $\begin{array}{l}\text { Nasdaq } \\
\text { Biotech }\end{array}$ & $\begin{array}{c}\text { NYSE } \\
\text { ARCA } \\
\text { Biotech }\end{array}$ & $\begin{array}{c}\text { NYSE } \\
\text { ARCA } \\
\text { Pharma }\end{array}$ & $\begin{array}{l}k \text {-means } \\
\text { Pharma }\end{array}$ & $\begin{array}{c}k- \\
\text { means } \\
\text { Biotech }\end{array}$ \\
\hline $2000-$ & 0.499 & 0.202 & 0.353 & 0.422 & 0.434 & 0.487 & 0.226 & 0.235 & 0.387 \\
\hline 2004 & & & & & & & & & \\
\hline $\begin{array}{l}2005- \\
2009\end{array}$ & 0.332 & 0.240 & 0.251 & 0.253 & 0.234 & 0.264 & 0.189 & 0.189 & 0.262 \\
\hline $\begin{array}{l}2010- \\
2015\end{array}$ & 0.298 & 0.159 & 0.177 & 0.226 & 0.234 & 0.253 & 0.141 & 0.161 & 0.260 \\
\hline
\end{tabular}


Table 3: Beta Estimates from 2000 to 2015

Beta estimates are calculated each year, and control for the Fama and French (1993) size and value factors. Panel A provides volatilities for each year, while Panel B provides volatilities for 5 -year intervals. All beta estimates are significant at the $1 \%$ level.

Panel A: Yearly

\begin{tabular}{c|ccccccc}
\hline & $\begin{array}{c}\text { Orphan } \\
\text { Drug }\end{array}$ & $\begin{array}{c}\text { S\&P } \\
500 \\
\text { Biotech }\end{array}$ & $\begin{array}{c}\text { Nasdaq } \\
\text { Biotech }\end{array}$ & $\begin{array}{c}\text { NYSE } \\
\text { ARCA } \\
\text { Biotech }\end{array}$ & $\begin{array}{c}\text { NYSE } \\
\text { ARCA } \\
\text { Pharma }\end{array}$ & $\begin{array}{c}k \text {-means } \\
\text { Pharma }\end{array}$ & $\begin{array}{c}k \text {-means } \\
\text { Biotech }\end{array}$ \\
\hline 2000 & 1.47 & 1.19 & 1.44 & 1.59 & 0.56 & 0.68 & 1.19 \\
2001 & 1.66 & 1.11 & 1.46 & 1.50 & 0.56 & 0.64 & 1.09 \\
2002 & 1.14 & 0.93 & 1.18 & 1.21 & 0.67 & 0.72 & 0.97 \\
2003 & 1.04 & 0.93 & 1.29 & 1.28 & 0.80 & 0.83 & 0.97 \\
2004 & 1.29 & 1.18 & 1.24 & 1.32 & 0.86 & 0.93 & 1.20 \\
2005 & 1.07 & 1.21 & 1.08 & 1.12 & 0.69 & 0.82 & 0.76 \\
2006 & 1.16 & 0.97 & 1.05 & 1.06 & 0.86 & 0.92 & 0.75 \\
2007 & 0.91 & 0.84 & 0.84 & 0.78 & 0.75 & 0.72 & 0.79 \\
2008 & 0.92 & 0.84 & 0.86 & 0.81 & 0.71 & 0.73 & 0.83 \\
2009 & 0.96 & 0.88 & 0.92 & 1.07 & 0.73 & 0.80 & 0.96 \\
2010 & 0.77 & 0.99 & 0.93 & 0.89 & 0.86 & 0.85 & 0.88 \\
2011 & 0.88 & 0.76 & 0.88 & 0.98 & 0.72 & 0.80 & 0.83 \\
2012 & 1.11 & 0.92 & 0.98 & 1.00 & 0.66 & 0.69 & 0.98 \\
2013 & 1.61 & 1.58 & 1.43 & 1.46 & 0.85 & 1.07 & 1.20 \\
2014 & 1.53 & 1.28 & 1.25 & 1.15 & 0.84 & 1.01 & 1.06 \\
2015 & 1.22 & 1.23 & 1.22 & 1.17 & 0.91 & 1.03 & 1.28 \\
\hline Entire & 1.05 & 0.93 & 1.06 & 1.10 & 0.66 & 0.72 & 0.95 \\
Sample & & & & & & &
\end{tabular}

Panel B: 5-year Intervals

\begin{tabular}{c|ccccccc}
\hline Interval & $\begin{array}{c}\text { Orphan } \\
\text { Drug }\end{array}$ & $\begin{array}{c}\text { S\&P } \\
500 \\
\text { Biotech }\end{array}$ & $\begin{array}{c}\text { Nasdaq } \\
\text { Biotech }\end{array}$ & $\begin{array}{c}\text { NYSE } \\
\text { ARCA } \\
\text { Biotech }\end{array}$ & $\begin{array}{c}\text { NYSE } \\
\text { ARCA } \\
\text { Pharma }\end{array}$ & $\begin{array}{c}k \text {-means } \\
\text { Pharma }\end{array}$ & $\begin{array}{c}k \text {-means } \\
\text { Biotech }\end{array}$ \\
\hline $2000-2004$ & 1.26 & 1.02 & 1.29 & 1.32 & 0.68 & 0.75 & 1.06 \\
$2005-2009$ & 0.97 & 0.87 & 0.89 & 0.87 & 0.72 & 0.75 & 0.83 \\
$2010-2015$ & 1.16 & 1.05 & 1.10 & 1.11 & 0.80 & 0.91 & 1.04 \\
\hline
\end{tabular}


Table 4: Yearly and Interval Maximum Drawdowns from 2000 to 2015

This table provides maximum drawdowns for the indicated time periods for each of the indexes. Panel A provides drawdowns for each year, while Panel B provides drawdowns for 5 -year intervals.

\section{Panel A: Yearly}

\begin{tabular}{|c|c|c|c|c|c|c|c|}
\hline Year & $\begin{array}{c}\text { Orphan } \\
\text { Drug }\end{array}$ & $\begin{array}{c}\text { S\&P } \\
500 \\
\text { Biotech }\end{array}$ & $\begin{array}{l}\text { Nasdaq } \\
\text { Biotech }\end{array}$ & $\begin{array}{c}\text { NYSE } \\
\text { ARCA } \\
\text { Biotech }\end{array}$ & $\begin{array}{c}\text { NYSE } \\
\text { ARCA } \\
\text { Pharma } \\
\end{array}$ & $\begin{array}{l}k \text {-means } \\
\text { Pharma }\end{array}$ & $\begin{array}{c}k-m e a n s \\
\text { Biotech }\end{array}$ \\
\hline 2000 & $-56.7 \%$ & $-35.7 \%$ & $-47.1 \%$ & $-49.0 \%$ & $-22.0 \%$ & $-15 \%$ & $-55.2 \%$ \\
\hline 2001 & $-55.0 \%$ & $-26.1 \%$ & $-38.4 \%$ & $-38.4 \%$ & $-19.6 \%$ & $-23 \%$ & $-40.8 \%$ \\
\hline 2002 & $-50.4 \%$ & $-48.5 \%$ & $-54.6 \%$ & $-51.0 \%$ & $-37.8 \%$ & $-39 \%$ & $-53.3 \%$ \\
\hline 2003 & $-27.2 \%$ & $-15.9 \%$ & $-17.3 \%$ & $-15.5 \%$ & $-13.7 \%$ & $-13 \%$ & $-17.0 \%$ \\
\hline 2004 & $-44.5 \%$ & $-14.3 \%$ & $-26.4 \%$ & $-20.8 \%$ & $-17.2 \%$ & $-18 \%$ & $-36.5 \%$ \\
\hline 2005 & $-30.5 \%$ & $-13.7 \%$ & $-15.4 \%$ & $-10.4 \%$ & $-9.6 \%$ & $-9 \%$ & $-16.5 \%$ \\
\hline 2006 & $-28.3 \%$ & $-14.9 \%$ & $-20.4 \%$ & $-17.7 \%$ & $-6.0 \%$ & $-9 \%$ & $-18.1 \%$ \\
\hline 2007 & $-15.6 \%$ & $-15.1 \%$ & $-9.8 \%$ & $-10.7 \%$ & $-12.3 \%$ & $-10 \%$ & $-15.5 \%$ \\
\hline 2008 & $-43.1 \%$ & $-28.1 \%$ & $-33.1 \%$ & $-38.9 \%$ & $-34.2 \%$ & $-30 \%$ & $-43.5 \%$ \\
\hline 2009 & $-30.3 \%$ & $-20.4 \%$ & $-20.9 \%$ & $-24.1 \%$ & $-21.1 \%$ & $-23 \%$ & $-26.6 \%$ \\
\hline 2010 & $-16.7 \%$ & $-20.5 \%$ & $-18.9 \%$ & $-20.6 \%$ & $-17.2 \%$ & $-14 \%$ & $-23.2 \%$ \\
\hline 2011 & $-21.2 \%$ & $-16.6 \%$ & $-22.9 \%$ & $-33.3 \%$ & $-15.4 \%$ & $-16 \%$ & $-28.1 \%$ \\
\hline 2012 & $-20.5 \%$ & $-9.1 \%$ & $-12.7 \%$ & $-12.9 \%$ & $-7.9 \%$ & $-8 \%$ & $-18.1 \%$ \\
\hline 2013 & $-15.5 \%$ & $-13.5 \%$ & $-9.9 \%$ & $-10.3 \%$ & $-6.5 \%$ & $-7 \%$ & $-12.6 \%$ \\
\hline 2014 & $-26.1 \%$ & $-18.4 \%$ & $-21.1 \%$ & $-19.6 \%$ & $-9.4 \%$ & $-10 \%$ & $-26.2 \%$ \\
\hline 2015 & $-32.7 \%$ & $-22.8 \%$ & $-27.2 \%$ & $-25.5 \%$ & $-15.9 \%$ & $-19 \%$ & $-33.7 \%$ \\
\hline $\begin{array}{l}\text { Entire } \\
\text { Sample }\end{array}$ & $-82.5 \%$ & $-60.1 \%$ & $-74.7 \%$ & $-65.0 \%$ & $-51.8 \%$ & $-48.2 \%$ & $-79.3 \%$ \\
\hline
\end{tabular}

Panel B: 5-year Intervals

\begin{tabular}{c|ccccccc}
\hline \multirow{2}{*}{ Interval } & $\begin{array}{c}\text { Orphan } \\
\text { Drug }\end{array}$ & $\begin{array}{c}\text { S\&P } \\
500 \\
\text { Biotech }\end{array}$ & $\begin{array}{c}\text { Nasdaq } \\
\text { Biotech }\end{array}$ & $\begin{array}{c}\text { NYSE } \\
\text { ARCA } \\
\text { Biotech }\end{array}$ & $\begin{array}{c}\text { NYSE } \\
\text { ARCA } \\
\text { Pharma }\end{array}$ & $\begin{array}{c}k \text {-means } \\
\text { Pharma }\end{array}$ & $\begin{array}{c}k \text {-means } \\
\text { Biotech }\end{array}$ \\
\hline $2000-2004$ & $-81.2 \%$ & $-60.1 \%$ & $-74.7 \%$ & $-65.0 \%$ & $-45.8 \%$ & $-48.2 \%$ & $-79.3 \%$ \\
$2005-2009$ & $-48.6 \%$ & $-30.2 \%$ & $-34.7 \%$ & $-38.9 \%$ & $-41.4 \%$ & $-37.4 \%$ & $-55.9 \%$ \\
$2010-2015$ & $-32.7 \%$ & $-22.8 \%$ & $-27.2 \%$ & $-33.3 \%$ & $-17.2 \%$ & $-19.0 \%$ & $-33.7 \%$ \\
\hline
\end{tabular}


Table 5: Sharpe Ratios from 2000 to 2015

This table provides Sharpe ratios for the indicated time periods for each of the indexes. Sharpe ratios are calculated using daily returns, and are annualized. Panel A provides Sharpe ratios for each year, while Panel B provides Sharpe ratios for 5-year intervals.

Panel A: Yearly

\begin{tabular}{|c|c|c|c|c|c|c|c|c|c|}
\hline Year & $\begin{array}{c}\text { Orphan } \\
\text { Drug }\end{array}$ & $\begin{array}{l}\text { S\&P } \\
500 \\
\end{array}$ & Nasdaq & $\begin{array}{l}\text { S\&P } 500 \\
\text { Biotech }\end{array}$ & $\begin{array}{l}\text { Nasdaq } \\
\text { Biotech }\end{array}$ & $\begin{array}{l}\text { NYSE ARCA } \\
\text { Biotech }\end{array}$ & $\begin{array}{c}\text { NYSE } \\
\text { ARCA } \\
\text { Pharma } \\
\end{array}$ & $\begin{array}{c}k- \\
\text { means } \\
\text { Pharma }\end{array}$ & $\begin{array}{c}k- \\
\text { means } \\
\text { Biotech }\end{array}$ \\
\hline 2000 & 1.004 & -0.628 & -0.896 & 0.140 & 0.551 & 0.950 & 0.777 & 0.761 & 0.390 \\
\hline 2001 & -0.374 & -0.728 & -0.424 & 0.042 & -0.224 & 0.031 & -0.890 & -0.836 & -0.477 \\
\hline 2002 & -0.959 & -0.956 & -0.975 & -0.306 & -1.140 & -0.936 & -0.824 & -0.786 & -0.645 \\
\hline 2003 & 0.316 & 1.396 & 1.887 & 1.109 & 1.387 & 1.319 & 0.668 & 0.660 & 0.432 \\
\hline 2004 & -0.440 & 0.727 & 0.502 & 0.404 & 0.326 & 0.509 & -0.452 & -0.421 & -0.260 \\
\hline 2005 & -0.016 & 0.052 & -0.064 & 0.741 & 0.084 & 1.038 & -0.113 & -0.103 & -0.046 \\
\hline 2006 & 0.445 & 0.860 & 0.383 & -0.380 & -0.139 & 0.394 & 0.311 & 0.314 & 0.195 \\
\hline 2007 & 1.239 & 0.010 & 0.361 & -0.300 & 0.074 & 0.057 & -0.469 & -0.489 & -0.401 \\
\hline 2008 & -0.602 & -1.014 & -1.094 & 0.404 & -0.247 & -0.414 & -0.570 & -0.584 & -0.504 \\
\hline 2009 & 0.709 & 0.904 & 1.423 & -0.185 & 0.709 & 1.255 & 0.761 & 0.714 & 0.496 \\
\hline 2010 & 1.889 & 0.746 & 0.881 & 0.186 & 0.791 & 1.428 & -0.017 & -0.016 & -0.010 \\
\hline 2011 & 1.460 & 0.115 & 0.053 & 1.105 & 0.563 & -0.464 & 0.560 & 0.526 & 0.345 \\
\hline 2012 & 1.214 & 1.055 & 1.065 & 1.829 & 1.600 & 1.675 & 1.052 & 0.995 & 0.551 \\
\hline 2013 & 1.608 & 2.399 & 2.710 & 2.470 & 2.533 & 1.983 & 2.227 & 1.791 & 1.262 \\
\hline 2014 & 1.052 & 1.006 & 0.960 & 1.204 & 1.263 & 1.615 & 1.086 & 0.835 & 0.493 \\
\hline 2015 & 0.515 & 0.030 & 0.415 & 0.318 & 0.528 & 0.512 & 0.180 & 0.150 & 0.091 \\
\hline $\begin{array}{l}\text { Entire } \\
\text { Sample }\end{array}$ & 0.444 & 0.118 & $\begin{array}{r}0.117 \\
\text { Pane }\end{array}$ & $\begin{array}{l}0.417 \\
5-y\end{array}$ & $\begin{array}{l}0.381 \\
\text { Interv }\end{array}$ & 0.535 & 0.145 & 0.138 & 0.088 \\
\hline Interval & $\begin{array}{c}\text { Orphan } \\
\text { Drug }\end{array}$ & $\begin{array}{l}\text { S\&P } \\
500 \\
\end{array}$ & Nasdaq & $\begin{array}{l}\text { S\&P } 500 \\
\text { Biotech }\end{array}$ & $\begin{array}{l}\text { Nasdaq } \\
\text { Biotech }\end{array}$ & $\begin{array}{c}\text { NYSE } \\
\text { ARCA } \\
\text { Biotech } \\
\end{array}$ & $\begin{array}{c}\text { NYSE } \\
\text { ARCA } \\
\text { Pharma } \\
\end{array}$ & $\begin{array}{l}k \text {-means } \\
\text { Pharma }\end{array}$ & $\begin{array}{c}k \text {-means } \\
\text { Biotech }\end{array}$ \\
\hline $2000-2004$ & 0.031 & -0.222 & -0.256 & 0.153 & 0.093 & 0.324 & -0.096 & -0.093 & -0.056 \\
\hline 2005-2009 & 0.245 & -0.064 & 0.049 & 0.118 & 0.078 & 0.441 & -0.085 & -0.085 & -0.062 \\
\hline $2010-2015$ & 1.243 & 0.713 & 0.833 & 1.166 & 1.141 & 1.047 & 0.729 & 0.639 & 0.397 \\
\hline
\end{tabular}

Table 6: Alpha Estimates from 2000 to 2015

This table provides alpha estimates for the indicated time periods for each of the indexes. Alphas are calculated using the Fama and French (1993) three-factor model, and are annualized. Panel A provides alphas for each year, while Panel B provides alphas for 5-year 
intervals. ${ }^{* * *}$ represents significance at the $1 \%$ level, ${ }^{* *}$ represents significance at the $5 \%$ level, and * represents significance at the $10 \%$ level.

Panel A: Yearly

\begin{tabular}{|c|c|c|c|c|c|c|c|}
\hline Year & $\begin{array}{l}\text { Orphan } \\
\text { Drug }\end{array}$ & $\begin{array}{c}\text { S\&P } \\
500 \\
\text { Biotech }\end{array}$ & $\begin{array}{l}\text { Nasdaq } \\
\text { Biotech }\end{array}$ & $\begin{array}{c}\text { NYSE } \\
\text { ARCA } \\
\text { Biotech }\end{array}$ & $\begin{array}{c}\text { NYSE } \\
\text { ARCA } \\
\text { Pharma }\end{array}$ & $\begin{array}{l}k \text {-means } \\
\text { Pharma }\end{array}$ & $\begin{array}{c}k \text {-means } \\
\text { Biotech }\end{array}$ \\
\hline 2000 & 1.239 & 0.420 & 0.886 & $1.712^{* *}$ & 0.222 & 0.333 & 0.633 \\
\hline 2001 & -0.166 & 0.334 & 0.063 & 0.267 & -0.118 & -0.115 & -0.147 \\
\hline 2002 & -0.106 & 0.232 & -0.133 & -0.037 & 0.017 & 0.022 & -0.272 \\
\hline 2003 & -0.306 & -0.001 & -0.120 & -0.082 & -0.018 & -0.042 & 0.351 \\
\hline 2004 & -0.253 & 0.019 & -0.042 & 0.019 & -0.081 & -0.070 & -0.130 \\
\hline 2005 & 0.057 & 0.228 & 0.069 & $0.300^{*}$ & 0.012 & 0.034 & 0.475 \\
\hline 2006 & 0.019 & -0.091 & -0.059 & 0.028 & -0.011 & 0.008 & -0.134 \\
\hline 2007 & 0.203 & -0.199 & -0.086 & -0.053 & $-0.117^{*}$ & -0.096 & -0.108 \\
\hline 2008 & 0.029 & $0.690^{* *}$ & 0.276 & 0.159 & 0.125 & 0.201 & -0.011 \\
\hline 2009 & -0.055 & -0.257 & -0.107 & 0.095 & -0.047 & -0.084 & -0.114 \\
\hline 2010 & 0.283 & -0.119 & -0.055 & 0.137 & -0.113 & -0.081 & -0.070 \\
\hline 2011 & $0.414^{*}$ & 0.180 & 0.093 & -0.180 & 0.068 & $0.131^{*}$ & -0.071 \\
\hline 2012 & 0.244 & 0.247 & 0.191 & 0.270 & 0.009 & 0.078 & 0.029 \\
\hline 2013 & -0.015 & 0.144 & 0.089 & -0.036 & 0.009 & 0.076 & 0.029 \\
\hline 2014 & 0.135 & 0.091 & 0.137 & 0.267 & -0.007 & 0.058 & 0.100 \\
\hline 2015 & -0.045 & -0.071 & -0.029 & -0.024 & -0.039 & -0.040 & -0.145 \\
\hline Entire & $0.134^{*}$ & $0.128^{* *}$ & 0.093* & $0.165^{* * *}$ & 0.009 & 0.047 & 0.023 \\
\hline
\end{tabular}

Sample

Panel B: 5-year Intervals

\begin{tabular}{c|ccccccc}
\hline \multirow{2}{*}{ Interval } & $\begin{array}{c}\text { Orphan } \\
\text { Drug }\end{array}$ & $\begin{array}{c}\text { S\&P } \\
500 \\
\text { Biotech }\end{array}$ & $\begin{array}{c}\text { Nasdaq } \\
\text { Biotech }\end{array}$ & $\begin{array}{c}\text { NYSE } \\
\text { ARCA } \\
\text { Biotech }\end{array}$ & $\begin{array}{c}\text { NYSE } \\
\text { ARCA } \\
\text { Pharma }\end{array}$ & $\begin{array}{c}k \text {-means } \\
\text { Pharma }\end{array}$ & $\begin{array}{c}k \text {-means } \\
\text { Biotech }\end{array}$ \\
\hline $2000-2004$ & -0.030 & 0.174 & 0.077 & 0.253 & -0.006 & 0.009 & 0.009 \\
$2005-2009$ & 0.075 & 0.041 & 0.016 & 0.117 & -0.011 & 0.009 & 0.009 \\
$2010-2015$ & $0.192 *$ & 0.104 & 0.093 & 0.091 & -0.011 & 0.044 & -0.016 \\
\hline
\end{tabular}




\section{Appendix}

\section{A.1 ORF Constituents}

\section{Table A1: Included Orphan Drug Companies}

This table lists the orphan drug companies of the ORF index, as well as the date range for which we have stock data.

\begin{tabular}{|c|c|c|c|}
\hline \multicolumn{2}{|r|}{ Company Name } & \multirow{2}{*}{$\frac{\text { Start Date }}{10 / 22 / 2010}$} & \multirow{2}{*}{$\frac{\text { End Date }}{12 / 31 / 2015}$} \\
\hline 1 & AEGERION PHARMACEUTICALS INC & & \\
\hline 2 & ZOGENIX INC & $11 / 18 / 2010$ & $12 / 31 / 2015$ \\
\hline 3 & MEDGENICS INC & $4 / 8 / 2011$ & $12 / 31 / 2015$ \\
\hline 4 & KAMADA LTD & $5 / 31 / 2013$ & $12 / 31 / 2015$ \\
\hline 5 & P T C THERAPEUTICS INC & $6 / 20 / 2013$ & $12 / 31 / 2015$ \\
\hline 6 & PROSENSA HOLDING N V & $6 / 28 / 2013$ & $2 / 12 / 2015$ \\
\hline 7 & AGIOS PHARMACEUTICALS INC & $7 / 24 / 2013$ & $12 / 31 / 2015$ \\
\hline 8 & CONATUS PHARMACEUTICALS INC & $7 / 25 / 2013$ & $12 / 31 / 2015$ \\
\hline 9 & ACCELERON PHARMA INC & $9 / 18 / 2013$ & $12 / 31 / 2015$ \\
\hline 10 & ULTRAGENYX PHARMACEUTICALS INC & $1 / 31 / 2014$ & $12 / 31 / 2015$ \\
\hline 11 & AUSPEX PHARMACEUTICALS INC & $2 / 5 / 2014$ & $5 / 5 / 2015$ \\
\hline 12 & APPLIED GENETIC TECHNOLOGIES COR & $3 / 27 / 2014$ & $12 / 31 / 2015$ \\
\hline 13 & CYMABAY THERAPEUTICS INC & $6 / 18 / 2014$ & $12 / 31 / 2015$ \\
\hline 14 & BIO BLAST PHARMA LTD & $7 / 30 / 2014$ & $12 / 31 / 2015$ \\
\hline 15 & SAGE THERAPEUTICS INC & $7 / 18 / 2014$ & $12 / 31 / 2015$ \\
\hline 16 & BRAINSTORM CELL THERAPEUTICS INC & $9 / 30 / 2014$ & $12 / 31 / 2015$ \\
\hline 17 & BELLICUM PHARMACEUTICALS INC & $12 / 18 / 2014$ & $12 / 31 / 2015$ \\
\hline 18 & SPARK THERAPEUTICS INC & $1 / 30 / 2015$ & $12 / 31 / 2015$ \\
\hline 19 & CORBUS PHARMACEUTICALS HLD INC & $4 / 16 / 2015$ & $12 / 31 / 2015$ \\
\hline 20 & NIVALIS THERAPEUTICS INC & $6 / 17 / 2015$ & $12 / 31 / 2015$ \\
\hline 21 & CHIASMA INC & $7 / 16 / 2015$ & $12 / 31 / 2015$ \\
\hline 22 & GLOBAL BLOOD THERAPEUTICS INC & $8 / 12 / 2015$ & $12 / 31 / 2015$ \\
\hline 23 & DIMENSION THERAPEUTICS INC & $10 / 22 / 2015$ & $12 / 31 / 2015$ \\
\hline 24 & STRONGBRIDGE BIOPHARMA PLC & $10 / 2 / 2015$ & $12 / 31 / 2015$ \\
\hline 25 & MARINA BIOTECH INC & $12 / 6 / 1993$ & $2 / 2 / 2012$ \\
\hline 26 & BIOCRYST PHARMACEUTICALS INC & $3 / 4 / 1994$ & $12 / 31 / 2015$ \\
\hline 27 & N P S PHARMACEUTICALS INC & $5 / 26 / 1994$ & $2 / 23 / 2015$ \\
\hline 28 & ALEXION PHARMACEUTICALS INC & $2 / 28 / 1996$ & $12 / 31 / 2015$ \\
\hline 29 & ARQULE INC & $10 / 16 / 1996$ & $12 / 31 / 2015$ \\
\hline 30 & SYNAGEVA BIOPHARMA CORP & $10 / 7 / 1997$ & $6 / 23 / 2015$ \\
\hline 31 & BIOMARIN PHARMACEUTICAL INC & $7 / 23 / 1999$ & $12 / 31 / 2015$ \\
\hline 32 & PLASMATECH BIOPHARMACEUTICALS IN & $3 / 30 / 2000$ & $12 / 31 / 2015$ \\
\hline 33 & ABEONA THERAPEUTICS INC & $3 / 30 / 2000$ & $12 / 31 / 2015$ \\
\hline 34 & RAPTOR PHARMACEUTICAL CORP & $4 / 3 / 2000$ & $12 / 31 / 2015$ \\
\hline
\end{tabular}




\begin{tabular}{|rlrr|}
\hline 35 & INSMED INC & $6 / 1 / 2000$ & $12 / 31 / 2015$ \\
\hline 36 & MAST THERAPEUTICS INC & $4 / 29 / 2004$ & $12 / 31 / 2015$ \\
\hline 37 & X T L BIOPHARMACEUTICALS LTD & $9 / 1 / 2005$ & $12 / 31 / 2015$ \\
\hline 38 & CATALYST PHARMACEUTICALS INC & $11 / 1 / 2006$ & $12 / 31 / 2015$ \\
\hline 39 & AMICUS THERAPEUTICS INC & $5 / 31 / 2007$ & $12 / 31 / 2015$
\end{tabular}

